\title{
ЙОДОДЕФІЦИТНІ ЗАХВОРЮВАННЯ У ПАЦІЄНТІВ ІЗ КОГНІТИВНИМИ ПРОЯВАМИ ТА ЇХ ПРОФІЛАКТИКА
}

\author{
С. О. Груба, У. О. Наумова \\ Тернопільський національний медичний університет \\ імені І. Я. Горбачевського МОз Украӥни
}

Йодну профілактику на сьогодні вважають одним з найдієвіших методів попередження станів, пов’язаних із дефіцитом йоду, а саме запобігання ендемічному зобу та зобу після резекції; лікування йододефіциту та дифузного еутиреоїдного зоба. Крім того, вчасно призначена йодна профілактика позитивно впливає на розумові здібності та посилює працездатність у людей різної вікової категорії.

\section{IODINE DEFICIENCY DISEASES IN PATIENTS WITH COGNITIVE MANIFESTATIONS AND THEIR PROPHYLAXIS}

\author{
S. O. Gruba, U. O. Naumova
}

\section{Horbachevsky Ternopil National Medical University}

Iodine prophylaxis is currently considered one of the most effective methods of preventing conditions that associated with iodine deficiency, namely the prevention of endemic goiter and goiter after resection; treatment of iodine deficiency and diffuse euthyroid goiter. In addition, timely assigned iodine prophylaxis has a positive effect on mental abilities and enhances working efficiency in people of all ages.

Вступ. У наш час про необхідність масового використання йоду медики вперше заговорили у зв'язку з різким збільшенням кількості захворювань щитоподібної залози після Чорнобильської катастрофи. З'ясувалося, що цей орган особливо зазнавав радіаційного ураження в тих осіб, в організмі яких не вистачало йоду. Адже йод становить основу гормонів щитоподібної залози, які виконують життєво важливі функції. Приміром, беруть участь в обміні речовин, процесах кровотворення, контролюють діяльність мозку, нервової системи, статевих і молочних залоз, ріст і розвиток дитини, поповнюють енергетичні ресурси організму, впливають на нервову та імунну системи, підвищують опірність до інфекцій та ракових клітин [1].

Для нормального функціонування щитоподібної залози (ЩЗ) людині на добу необхідно отримувати 100-200 мкг йоду. Тривалий дефіцит йоду, а також ситуації, що вимагають підвищеної кількості тиреоїдних гормонів (ТГ), зокрема вагітність, можуть призвести до зриву механізмів адаптації з наступним розвитком

(ㄱ С. О. Груба, У. О. Наумова, 2020 цілого ряду захворювань, зумовлених впливом йодної недостатності на ріст і розвиток організму [2, 3].

Основна частина. Психомоторні порушення, що виникли на етапі розвитку мозку, усунути неможливо, але їх можна попередити. У зв'язку з цим, найбільшого значення набуває профілактика і лікування йодної недостатності на максимально ранніх термінах гестації, оскільки профілактичні заходи, що проводять після I триместру вагітності, не можуть поліпшити інтелектуальні можливості дитини [4]. Найбільш оптимальною $є$ профілактика йододефіцитних захворювань (ЙДЗ) у всіх жінок фертильного віку, особливо у тих, хто планує вагітність. Останні обов'язково повинні бути оглянуті ендокринологом, при необхідності їм потрібно визначити обсяг ЩЗ, їі функціональну активність. Якщо в результаті обстеження виключені патологічні стани щ3, що вимагають лікування до настання вагітності (тиреотоксикоз, гіпотиреоз, рак щ3 і т. д.), жінкам на етапі прегравідарної підготовки призначають адекватну йодну профілактику - 200 мкг йоду на добу (рекомендації вОО3) [5]. Йодну профілактику необхідно продовжувати і призначати під 
час вагітності у вигляді препаратів йоду або мінерально-вітамінних комплексів для вагітних. Варто зазначити, що не у всіх комплексних препаратах для вагітних міститься йод або його кількість $\epsilon$ недостатньою для періоду вагітності (як правило, в таких комплексах міститься 100-150 мкг йоду). У таких випадках обов'язково треба додати до терапії 50-100 мкг йодиду калію, залежно від вмісту йодиду в комплексі, а при його відсутності - 200 мкг йоду. 3 метою індивідуальної йодної профілактики у вагітних жінок не слід використовувати йодовмісні біологічно активні добавки. Тільки індивідуальне призначення точно дозованих лікарських препаратів йоду забезпечує достатнє надходження мікроелемента під час вагітності для росту і розвитку плода і забезпечує профілактику найтяжчих Йдз.

Єдиним протипоказанням для призначення індивідуальної йодної профілактики під час вагітності $\epsilon$ патологічний тиреотоксикоз (хвороба Грейвса, тиреотоксична аденома). Носійство антитіл до тиреоїдної пероксидази (АТ до ТПО) не $є$ протипоказанням до призначення препаратів йоду, хоча і вимагає динамічного контролю функції щЗ протягом вагітності. Якщо вагітна отримувала монотерапію левотироксином ще до вагітності, то з метою індивідуальної йодної профілактики їй також необхідно призначити 200 мкг йоду.

Дослідження, проведені Всесвітньою організацією охорони здоров'я у різних країнах, показали, що рівень розумового розвитку безпосередньо пов'язаний з достатністю йоду в організмі. Гормональні порушення, які виникають через нестачу цієї речовини в організмі, можуть не проявлятися ззовні. Тому йододефіцит отримав назву «прихований голод». Від цього голоду особливо потерпають діти. Їм важко вчитися в школі, запам'ятовувати новий матеріал. Тож сьогодні на державному рівні порушують питання щодо заходів йодопрофілактики населення.

Добова потреба в йоді залежить від віку, функціонального стану (період статевого дозрівання, вагітність і період годування груддю потребують більшої кількості йоду.)

Всесвітня організація охорони здоров'я рекомендує такі добові дози йоду:

- 50 мкг для дітей грудного віку;

- 90 мкг - дошкільнятам (2-6 років);

- 120 мкг - школярам (7-12 років);

- 150 мкг - для підлітків і дорослих;

- 100 мкг - для осіб старшого віку;

- 200 мкг - для вагітних та жінок, які годують груддю.
Нестача йоду в організмі може проявлятися збільшенням маси тіла, слабістю, млявістю, швидкою стомлюваністю, сповільненням розумових процесів. При дефіциті йоду знижується пам'ять, з'являються роздратованість і підвищена чутливість до холоду, випадає волосся, шкіра втрачає вологість, ужінок порушується менструальний цикл. Нестача цього мікроелемента негативно впливає на репродуктивність жінок, що проявляється мимовільними абортами, мертвонародженнями, аномаліями плода, безпліддям.

Клінічними проявами йододефіциту є порушення розумового та психічного розвитку різного ступеня.

Доведено, що дефіцит йоду може призвести до негативних змін спадковості - порушень в хромосомах і схильності до онкозахворювань.

Для того, щоб виправити ситуацію, необхідно, щоб організм у достатній кількості отримував препарати йоду.

Важливо те, що усунення йододефіциту - цілком реальна справа, наслідком якої стане суттєве поліпшення здоров'я населення. Тому вже в 1990 р. на сесії ООН було прийнято звернення до всіх країн світу із закликом спрямувати зусилля на ліквідацію Йдз. На думку спеціалістів Всесвітньої організації охорони здоров'я, ліквідація йододефіцитних захворювань $\epsilon$ одним із найбільш важливих завдань охорони здоров'я наприкінці другого та на початку третього тисячоліття. Усунення захворювань, пов'язаних із дефіцитом йоду, вітаміну А, заліза в організмі, на думку спеціалістів, за своєю значущістю перевершує таке досягнення медицини, як ліквідація віспи.

При тяжкій нестачі йоду спостерігаються виражені форми зоба майже у всіх жителів та значна поширеність випадків затримки розумового розвитку, аж до крайніх його проявів, наприклад, кретинізму. Разом із тим, недостатнє надходження, засвоєння, порушення інтрафолікулярного транспорту та органіфікації йодиду в щитоподібній залозі $є$ головними причинами розвитку не тільки ендемічного зоба, але й гіпотиреозу, спорадичних форм вузлового та дифузного зоба, при яких інтратиреоїдний дефіцит йоду виступає самостійним фактором проліферації тиреоцитів, а також сприяє збільшенню частоти випадків низькодиференційованих пухлин цієї залози.

Йодна профілактика повинна бути проведена під контролем лікаря. Завдання ліквідації Йдз у всьому світі визнано актуальним у медичному та соціальноекономічному аспектах, оскільки ці захворювання впливають на стан здоров'я населення, інтелектуаль- 
ний, освітній та професійний потенціал суспільства. Йододефіцитні захворювання $є$ однією з найактуальніших проблем охорони здоров'я для більш ніж 140 країн світу.

Висновки. Впровадження йодної профілактики в Україні $є$ нагальним завданням, що не тільки дозволить усунути ряд проявів тиреоїдної патології, але й

\section{СПИСОК ЛІТЕРАТУРИ}

1. Кравченко В. І. Йодний дефіцит як причина високої розповсюдженості тиреоїдної патології серед населення регіонів, що постраждали після аварії на ЧАЕС / В. І. Кравченко // Журнал НАМН України. - 2016. - № 2 (22). C. 222-229.

2. Маменко М. Є. Йодний дефіцит та йододефіцитні захворювання / М. Є. Маменко // Перинатологія і педіатрія. - 2013. - № 1 (53). - С. 97-105.

3. Паньків В. І. Ендемічний зоб (йододефіцитні захворювання) / В. І. Паньків // Новости медицины и фармации. - 2013. - № 8. - С. 3-5. значно покращити здоров'я населення. Застосування системи моніторингу дозволить підвищити ефективність йодної профілактики та уникнути негативних ії наслідків. Йодна профілактика запобігає виникненню когнітивних проявів і покращує розумові здібності у будь-якому віці.

4. Паньків В. І. Йодний дефіцит і вагітність: стан проблеми та шляхи її вирішення / В. І. Паньків // Здоров'я України. - 2018. - № 5 (14). - С. 27-34.

5. Про затвердження протоколів надання медичної допомоги дітям за спеціальністю «Дитяча ендокринологія» : наказ МОЗ України від 27.04.2006 р. № 254.

Отримано 03.12.20 